\title{
Protocol
}

\section{Purification of His-Tagged Proteins Using Fractogel-Cobalt}

\author{
Roseanne Tom, Louis Bisson, and Yves Durocher
}

This protocol was adapted from "Transient Expression in HEK293-EBNA1 Cells," Chapter 12, in Expression Systems (eds. Dyson and Durocher). Scion Publishing Ltd., Oxfordshire, UK, 2007.

\section{INTRODUCTION}

Fast and efficient production of recombinant proteins ( $r$-proteins) remains a major challenge for the academic and biopharmaceutical communities. Such proteins often need to be as pure as possible before any characterization study can begin. Although many types of protein tag are available, histidine is the most popular. Although small-scale immobilized metal-affinity column (IMAC) purification of such proteins (e.g., $<500 \mathrm{~mL}$ of culture medium) can easily be achieved using gravity chromatography columns, larger volumes can be processed with the aid of automated chromatography systems. This protocol describes an IMAC purification technique for secreted proteins using a cobalt-loaded resin. Preliminary small-scale trials using this technique can be used to determine the production scale that will be needed to provide enough pure material for a given study.

\section{RELATED INFORMATION}

A number of protocols are available for large-scale transfection of mammalian cells for production of milligram to gram quantities of r-proteins (e.g., Jordan et al. 1998; Schlaeger and Christensen 1999; Durocher et al. 2002; Baldi et al. 2005). Additional protocols can be found in this issue, including Transfection of HEK293-EBNA1 Cells in Suspension with Linear PEI for Production of Recombinant Proteins, Transfection of Adherent HEK293-EBNA1 Cells in a Six-Well Plate with Branched PEI for Production of Recombinant Proteins, and Transfection of HEK293-EBNA1 Cells in Suspension with 293fectin for Production of Recombinant Proteins. For a review of the use of affinity tags for purifying recombinant proteins, see Arnau et al. (2006).

\section{MATERIALS}

CAUTIONS AND RECIPES: Please see Appendices for appropriate handling of materials marked with $\langle$ ! $>$, and recipes for reagents marked with $<\mathbf{R}>$.

\section{Reagents}

All solutions (including the culture supernatant) must be filtered $(0.45 \mu \mathrm{m})$ and degassed to minimize air bubble formation in the column.

$<$ R $>$ Cleaning buffer

$<!>200 \mathrm{mM}$ Cobalt chloride $\left(\mathrm{CoCl}_{2}\right)$

$<$ R $>$ Cobalt stripping buffer

Culture supernatant

For large volumes of culture medium, concentrate the clarified culture supernatant 10- to 20-fold by tangential flow ultrafiltration prior to r-protein capture on the IMAC column. 


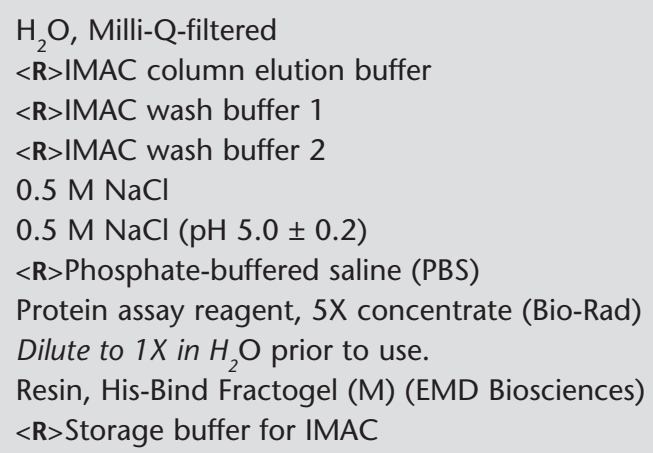

Equipment

Column, chromatography (e.g., Qiagen-tip 500 Maxi kit [2-cm diameter, 5-mL minimum bed volume] or HiSpeed Maxi Tip [3.5-cm diameter, 10-mL minimum bed volume])

For small-scale trials (20-500 mL), pack a gravity column with 1-5 mL of resin, with a bed height of at least $1 \mathrm{~cm}$.

Column, desalting, disposable, prepacked (e.g., Econo-Pac 10DG; Bio-Rad)

Microplate reader (optional; see Step 13)

Pipette

Plates, 96-well

Pump, peristaltic (optional, for large volumes; see Step 6.ii)

Spectrophotometer

Tubes, $1.5-\mathrm{mL}$

\section{METHOD}

\section{Column Charging}

1. Pack a gravity column with Fractogel resin.

Refer to the manufacturer's binding capacity specifications in order to use an adequate volume of resin.

2. Add five column-volumes of $0.5 \mathrm{M} \mathrm{NaCl}$.

3. Add four column-volumes of $200 \mathrm{mM} \mathrm{CoCl}$.

4. Add two column-volumes $0.5 \mathrm{M} \mathrm{NaCl}(\mathrm{pH} 5 \pm 0.2)$.

\section{Sample Loading and r-Protein Elution}

Use SDS-PAGE analysis on reserved 500- $\mu$ L aliquots of the original sample feed, flowthrough, washes, and pooled protein fractions to determine whether the purification process is sufficient or whether the column resin is overloaded beyond its protein-binding capacity.

5. Add 10 column-volumes of PBS to equilibrate the column.

6. Load the feed onto the column:

\section{For small volumes $(<100 \mathrm{~mL})$}

i. Allow the sample to pass through the column by gravity.

For large volumes (>100 $\mathrm{mL}$ )

ii. Attach a peristaltic pump to the column outlet to pull the sample feed through the column more quickly.

iii. Use a flow rate up to a maximum of $10 \mathrm{~mL} / \mathrm{min}(190 \mathrm{~cm} / \mathrm{h})$ for a $5-\mathrm{mL}$ Qiagen-tip 500 column or $20 \mathrm{~mL} / \mathrm{min}(125 \mathrm{~cm} / \mathrm{h})$ for a $10-\mathrm{mL}$ HiSpeed Maxi Tip column. 
iv. Stop and disconnect the pump 1-2 min before the entire sample empties from its reservoir.

v. Add the last few milliliters of sample to the reservoir with a pipette. Allow it to flow through by gravity.

This prevents the column from drying out.

7. Keep the flowthrough and store at $4^{\circ} \mathrm{C}$. Retain a $500-\mu \mathrm{L}$ aliquot for subsequent gel analysis. Do not discard the flowthrough or wash fractions until it has been determined that the r-protein has been entirely captured and eluted from the column.

8. Add 10 column-volumes of IMAC wash buffer 1 . Retain a $500-\mu \mathrm{L}$ aliquot of the flowthrough for subsequent gel analysis.

9. Add 10 column-volumes of IMAC wash buffer 2 to remove impurities bound to the column. Retain a 500- $\mu \mathrm{L}$ aliquot of the flowthrough for subsequent gel analysis.

10. Add four column-volumes of IMAC column elution buffer in 1-mL increments. Harvest individual 1 -mL fractions in prelabeled 1.5-mL tubes.

11. Add 5-20 $\mu \mathrm{L}$ of each eluted fraction to a 96-well plate.

12. Add $200 \mu \mathrm{L}$ of diluted protein assay reagent to each well. Make sure that each sample is well mixed as the reagent is being added.

13. Wait 5-10 min for color development.

The wells with the darkest blue coloration correspond to the fractions containing the r-protein. For more quantitative determination, read the absorbance at $595 \mathrm{~nm}$ using a microplate reader.

See Troubleshooting.

14. Pool the $1-\mathrm{mL}$ fractions containing r-protein.

15. Desalt the purified $r$-protein using a desalting column equilibrated in PBS or in your preferred buffer.

16. Based on the molar extinction coefficient of the protein, determine its concentration after measuring its absorbance at $280 \mathrm{~nm}$ (use an appropriate buffer as the blank).

The molar extinction coefficient of your protein can be obtained by uploading its amino acid sequence at http://ca.expasy.org/tools/protparam.html.

\section{Column Washing and Storage}

17. Add two column-volumes of cobalt stripping buffer to the column.

18. Add two column-volumes of $\mathrm{H}_{2} \mathrm{O}$.

19. Add 15 column-volumes of cleaning buffer.

20. Add five column-volumes of $\mathrm{H}_{2} \mathrm{O}$.

21. Add five column-volumes of PBS (or more if necessary) to neutralize the $\mathrm{pH}$ of the column to 7.0-7.2.

22. Add five column-volumes of storage buffer for IMAC.

23. Add an additional 1-2 $\mathrm{mL}$ of storage buffer for IMAC on top of the column. Cover the top and bottom. Store at $4^{\circ} \mathrm{C}$.

\section{TROUBLESHOOTING}

Problem: Purification from IMAC does not work.

[Step 13]

Solution: Consider the following:

1. Perform SDS-PAGE analysis of the feed, flowthrough, washes, and pooled fractions to see whether the r-protein was captured by the resin or not. If the His-tagged protein is in the flowthrough, the tag on the protein itself may be sterically hindered and inaccessible for capture by the column. 
2. The r-protein could be aggregated, thus hampering its capture onto the column. Check this by gel filtration chromatography.

3. Increasing the $\mathrm{pH}$ of the feed to 8.0 or higher can enhance r-protein binding to the column, and charging the IMAC column with nickel instead of cobalt can increase binding affinity.

4. Sometimes, the r-protein elutes in IMAC wash buffer 2. In this case, decrease the imidazole concentration of the wash buffer.

\section{REFERENCES}

Arnau, J., Lauritzen, C., Petersen, G.E., and Pedersen, J. 2006 Current strategies for the use of affinity tag and tag removal for the purification of recombinant proteins. Protein Expr. Purif. 48: $1-13$.

Baldi, L., Muller, N., Picasso, S., Jacquet, R., Girard, P., Thanh, H.P., Derow, E., and Wurm, F.M. 2005. Transient gene expression in suspension HEK-293 cells: Application to large-scale protein production. Biotechnol. Prog. 21: 148-153.

Durocher, Y., Perret, S., and Kamen, A. 2002. High-level and highthroughput recombinant protein production by transient trans- fection of suspension-growing human 293-EBNA1 cells. Nucleic Acids Res. 30: E9. doi: 10.1093/nar/30.2.e9.

Jordan, M., Köhne, C., and Wurm, F.M. 1998. Calcium-phosphate mediated DNA transfer into HEK-293 cells in suspension: Control of physicochemical parameters allows transfection in stirred media. Transfection and protein expression in mammalian cells. Cytotechnology 26: 39-47.

Schlaeger, E.-J. and Christensen, K. 1999. Transient gene expression in mammalian cells grown in serum-free suspension culture. Cytotechnology 30: 71-83. 


\section{Purification of His-Tagged Proteins Using Fractogel-Cobalt}

Roseanne Tom, Louis Bisson and Yves Durocher

Cold Spring Harb Protoc; doi: 10.1101/pdb.prot4980

\begin{tabular}{|c|c|}
\hline $\begin{array}{r}\text { Email Alerting } \\
\text { Service }\end{array}$ & Receive free email alerts when new articles cite this article - click here. \\
\hline \multirow{2}{*}{$\begin{array}{l}\text { Subject } \\
\text { Categories }\end{array}$} & Browse articles on similar topics from Cold Spring Harbor Protocols. \\
\hline & $\begin{array}{l}\text { Affinity and Immunoaffinity Chromatography (57 articles) } \\
\text { Chromatography, general (134 articles) } \\
\text { High-Throughput Analysis, general (155 articles) } \\
\text { Molecular Biology, general (1293 articles) } \\
\text { Proteins and Proteomics, general (575 articles) } \\
\text { Proteome Analysis (56 articles) } \\
\text { Tagging Proteins ( } 57 \text { articles) }\end{array}$ \\
\hline
\end{tabular}

